\title{
How 'public' is communicated in China's public diplomacy: communicating environmental justice in the case of air pollution in China
}

\author{
XIN ZHAO, Bournemouth University, Beijing Normal University-Hong Kong Baptist \\ University United International College
}

\section{ABSTRACT}

This study re-evaluates the media communications of the domestic public's interests related to environmental justice in the case of China's air pollution in China's public diplomacy initiatives. It examines media representations of environmental justice by China's statesponsored China Daily, and compares them with the Hong Kong-based South China Morning Post, and British and American mainstream newspapers. The examination starts from 2015, when Beijing issued the first ever red alert for air pollution, to 2018, when air pollution still haunted the country. This study finds that, besides the general policy schemes of smog mitigation, China Daily extended coverage to the general causes of smog and the domestic public's detailed demands for smog mitigation. It mainly adopted a neutral tone in covering environmental justice. The obvious discrepancy in coverage patterns between China Daily and other news media appears in the tone of covering 'adequacy' in environmental justice, with the former being neutral and the latter adopting more critical voices. This study offers a better understanding of China's evolving governmental stances in dealing with environmental justice issues in the case of air pollution.

\section{KEYWORDS}

Environmental Justice, Air Pollution, China, Media Representation, Public Diplomacy

\section{Introduction}

The increasing number and severity of environmental problems is putting pressure on nation states to react. ${ }^{1}$ Governmental reactions to environmental issues with human interests involved are one of the driving factors of the evolving landscape of global environmental politics. Since former US President Donald Trump announced the withdrawal of the US from the Paris Climate Agreement in 2017, China has arguably been viewed as taking over as a key player in global environmental politics. This shift puts China under the spotlight regarding its management of domestic environmental problems, especially its air pollution issues (Chen, Tu and Zheng 2017). In 2015, Beijing issued the first ever red alert, the highest level of alert, for

\footnotetext{
1 This work was partially supported by the United International College Research Grant under grant number R201929. The author would like to thank Iris Li for her assistance in data analysis.
} 
air pollution (Guo and Li 2018). However, the continuous governmental initiatives to tackle air pollution (Kopra 2015) have not conclusively resolved the issues (Beijing Municipal Ecological Environment Bureau 2018). Constant global scrutiny, especially from Western mainstream media including the BBC (BBC News 2015), CNN (Hunt and Lu 2015), and New York Times (Wong 2015), may push Chinese state actors to construct and clarify the country's position on air pollution issues, in which its domestic public's stakes are heavily involved in the global arena.

One of the most prominent aspects of environment-related issues is environmental justice, which is an idea developed based on the concern of equality of well-being for people (Quan 2002). Environmental justice became widely discussed in the context of China's air pollution (Ouyang et al. 2018; Sun, Khan and Zheng 2017). Moreover, the call to focus on the public's interests in environmental justice has also been reiterated in international academic studies (e.g., Moernaut, Mast and Pepermans 2018). Therefore, it is of vital importance to enrich our academic understandings of how the Chinese government strategically communicates domestic public's interests related to environmental justice to overseas audiences. It can shed light on the agendas of the Chinese government in communicating its policies related to environmental justice in the global community.

Public diplomacy is the strategic communication initiated by a practicing country with foreign publics, through channels such as news media, to achieve mutual understandings of values and policies of the practicing country, manage a favourable country image, and establish legitimacy (Golan 2013; Nye 2008). Empirical studies found successful examples of this communication, including South Korea in engaging with foreign public (Park and Lim 2014), and China and the US in strengthening their climate-related diplomatic networks (Yang, Wang and Wang 2017). One of the key elements of public diplomacy communication is the country's management of the domestic public's interests, which constitutes an essential aspect of the country's image (Buhmann and Ingenhoff 2015; Yun 2006).

The Chinese government embraces the idea of public diplomacy, and strategically constructs and communicates China's policies and values to foreign publics through state-sponsored outward focused news media (Huang and Wang 2019). Existing studies have extensively examined the outcome (e.g., Cheng, Golan and Kiousis 2016; Zhang et al. 2018) and the underlying political and economic issues (e.g., Hartig 2015; Sun 2014) in China's public diplomacy communication. In response to the textual turn of public diplomacy research (Zhao 2021), this study focuses on the message of China's public diplomacy communication. Studies of China's outward-focused communication of the domestic public's interests involved in the case of China's air pollution mainly focused on relevant media representations before 2015 (e.g., Chen 2018; Liu and Li 2017; Liu and Zhang 2018). Given the global pressure on China's governmental policies to deal with air pollution, especially after the first red alert in 2015, it is important to re-evaluate relevant journalistic representations by Chinese outward-focused media, which is a part of China's legitimisation of its policies in the global range. Specifically, this study attempts to see how the Chinese government has strategically communicated its domestic public's interests as an essential element of China's governmental stance on air 
pollution mitigation (country self-image) and how the communication negotiated, or contested, with its country image perceived by other countries, especially their mainstream media.

This study is composed of six parts. Following the introduction, the study rationalises the communication of 'public' in public diplomacy, and reviews existing literature on relevant practices in China. It then focuses on studies of China's public diplomacy communication of environmental justice issues and calls for an updated investigation of this topic in the context of China's ongoing air pollution and evolving international politics. The fourth section outlines this study's methodology and details the sampling procedures, unit of analysis, and the method of qualitative content analysis. The research findings are presented in a combination of frequencies of codes and interpretative quotations, followed by the discussion and conclusion. Overall, this study finds that China's state-sponsored news media China Daily $(C D)$ extended coverage from the general policy schemes of smog mitigation to the general causes of smog and the domestic public's detailed demands for smog mitigation. $C D$ mainly adopted a neutral tone in covering environmental justice. $C D$ and news media in Hong Kong, the UK, and the US differed in the tone of covering 'adequacy' in environmental justice, with the former being neutral and the latter adopting more critical voices.

\section{Communicating 'Public' in Public Diplomacy}

Public diplomacy activities are meant to strike a balance between a country image which points to foreign publics' perceptions of the country, and a country self-image (also labelled as country identity) which refers to the country's collective self-perception (Buhmann and Ingenhoff 2015; Entman 2008). A country self-image goes through a negotiation process between the self-perception of a country by its citizens collectively and the country image constructed by foreign publics (Ruscinao 2003). In other words, setting the tone for a country's policies in the global arena through the channel of public diplomacy is a two-dimensional process. Considering the diversity of domestic publics in China (Buhmann and Ingenhoff 2015), this study also considers the image of China constructed by English-language commercial news media in China's special administrative regions (SARs) of Hong Kong and Macau, which enjoy a larger degree of freedom but are still under the scrutiny of the Chinese government (Chen 2018; Krumbein 2015). This image is considered as being situated between country self-image and country image.

A country image is composed of 1) foreign publics' knowledge about a country's attributes (what foreign publics say) and 2) their affective evaluation of the country and its attributes (how foreign publics say it) (Buhmann and Ingenhoff 2015). One essential aspect of the attributes of a country image is the country's social and ecological responsibility towards its domestic public, which directly influences foreign publics' interest in and rapport with the country (Buhmann and Ingenhoff 2015, 115). Similarly, Seong-Hun Yun $(2006,302)$ included the concern of people's well-being domestically and internationally in 'humanitarian, developmental, human rights, and environmental issues' as one of the ethical measurements of the excellence of a country's public diplomacy activity. 
The Chinese government has communicated its domestic responsibility towards its citizens in various issues, such as human rights and HIV/AIDS management, to overseas audiences through state-sponsored media channels. Existing studies have explored its communication patterns in comparison with those by other news media. For example, when covering human rights protection, Frédéric Krumbein (2015) noticed the contrast between $C D$ and other news media such as New York Times (NYT) and South China Morning Post (SCMP). Although the former increased the amount of coverage of human rights from 1998 to 2008, it silenced the problems embedded in China's political and civil rights and positively depicted China's development in human rights protection, while the latter two negatively covered the human rights violation in China (Krumbein 2015). Similarly, little congruence was identified in covering China's HIV/AIDS management between China's official Xinhua News Agency (Xinhua) and the American Associated Press (AP) (Wu 2006). While Xinhua defended China's governmental measures towards the HIV/AIDS problem, optimistically depicted China's progress, and blurred factual information about its HIV/AIDS management, AP negatively constructed a dishonest, abusive, and incompetent image of China on the same issue (Wu 2006). On the contrary, in communicating the annual 'Two Sessions' on Twitter, Chinese state actors covered issues such as society and livelihood and reached issue congruence with overseas audiences in these aspects (Jia and Li 2020). ${ }^{2}$ Nevertheless, in communicating human rights issues, while Chinese officials explained them from perspectives of judicial and poverty elimination efforts, overseas audiences linked human rights in China to the political dominance of freedom of speech (Jia and Li 2020).

A country's responsibility towards its citizens in environmental issues is also an important part of its image construction and projection (Buhmann and Ingenhoff 2015; Yun 2006). China has been dealing with a range of environmental issues in recent years, including water, land, and air pollution, and forest deterioration (Yang, Wang and Wang 2017). It has been leveraging the state-sponsored English-language news media platforms to communicate its policies and activities in tackling these issues (e.g., Chen 2018; Liu and Li 2017; Zhao 2021). This study will specifically focus on China's communication of air pollution and the associated environmental justice issues through its outward-focused news media.

\section{China's Air Pollution, Environmental Justice, and Media Representation}

China's ascending economy is accompanied by environmental degradation, especially air pollution. The heavy concentration of the pollutant PM 2.5 in the air (Chen et al. 2017; Liu and Li 2017) can cause damage to the population's health (Chen 2018). On 7 December 2015, Beijing issued the first ever red alert, the highest warning level, for heavy air pollution. Although the Chinese government has been investing in administrative and technological measures to tackle air pollution (Kopra 2015), the choking smog came back again in 2018 (Beijing Municipal Ecological Environment Bureau 2018). One of the severe issues emerging from China's air pollution is environmental injustice. Ruixue Quan (2002, 464) defined

\footnotetext{
2 Two Sessions' refers to the annual meetings of the National People's Congress and the Chinese People's Political Consultative Conference National Committee in March in China (Jia and Li 2020).
} 
environmental justice in China as:

[...] fair treatment for people of all races, incomes and occupations, regardless of gender, residence, educational level, age, political position or background, regarding the development, implementation and enforcement of environmental laws, regulations, policies, and meaningful involvement in the decision-making processes of the government, and the fair distribution of environmental burdens and benefits to all. (2002, 464)

Research revealed the correlation between unequal exposure to PM 2.5 and age, education, and cancer morbidity in China (Ouyang et al. 2018). To fight the effects of air pollution, middleand high-income groups are more likely to invest in more expensive and effective selfprotection measures than low-income groups, indicating the inequality in smog mitigation in urban China (Sun, Khan and Zheng 2017).

Existing studies (e.g., Chen 2018; Liu and Li 2017) found that China's public diplomacy initiatives actively used outward-focused news media to communicate China's governmental stances and measures in dealing with air pollution to the global audience. The studies mainly focused on relevant media representations before 2015. Their results showed that China's statesponsored media touched upon the notion of environmental justice mainly from the perspectives of the transparency of information about air pollution and China's governmental measures to deal with it. For example, Sibo Chen (2018) identified that China's Xinhua and $C D$ acknowledged the serious damage of smog caused to Beijing residents in January 2013. On the contrary, Ming Liu and Chaoyuan Li (2017) found that although CD (2011-2014) acknowledged that China's smog had consequences for residents, it bypassed the detriment caused by smog to the public's health. In terms of discursive construction strategies, Ming Liu and Yiheng Zhang (2018) observed that $C D$, from 2011 to 2014, complicated and mystified the causes of health problems by air pollution, thus constructing the uncertainty of smog's harm to residents. Interestingly, Yumin Chen's (2014) study observed an attitudinal shift on the part of $C D$ in constructing China's air pollution from ignorance of the issue to the negative evaluation of the impact of air quality on China's residents' health from late 2011 to early 2013.

Similar to Chen (2018), Liu and Li (2017) also uncovered that China's outward-focused media highlighted and glorified the responsibilities fulfilled by the Chinese government in combating air pollution. The positive evaluation shaped a sheer contrast with the criticism levelled against the Chinese government about its "'active yet non-apologetic" stance' by SCMP and AP (Chen 2018, 394) and its 'inaction and artifice' by Anglo-American newspapers (Liu and Li 2017, 399). Ran Duan and Bruno Takahashi (2017) also identified that $C D$ most frequently mentioned Chinese governmental strategies to deal with the pollution from 2008 to 2013, in contrast to the NYT which focused more on topics such as the air pollution's negative social impact and the associated health risks. Unlike the pro-China tone applied by China's statesponsored media identified in other studies (e.g., Chen 2018; Liu and Li 2017), Duan and Takahashi (2017) found that $C D$ mostly adopted a neutral tone in framing issues of air pollution while the NYT was more critical in coverage and did not mention China's pollution mitigation progress at all. 
Apart from the information transparency about air pollution and China's governmental initiatives to tackle air pollution, other aspects of environmental justice were seldom addressed in China's state-sponsored outward-focused news media. For example, Chen (2018) found that Xinhua and $C D$ silenced the voices of vulnerable groups of people, such as migrant workers in Beijing, in the case of air pollution.

Nevertheless, besides the sheer difference of construction between China's state-sponsored media and other news media as mentioned above, Chen (2018) also found that the acknowledgement of the health risks of air pollution by Xinhua and $C D$ resonated with the coverage by SCMP and AP. Moreover, Chen (2014) discovered that $C D$ brought forward a shared identity between China and other countries in tackling air pollution by, for example, acknowledging Western experience in combating air pollution problems and mentioning the business opportunities generated by air pollution to both domestic and global markets. In other words, the construction of China's image in dealing with environmental justice issues in the case of air pollution by China's state-sponsored media might have gone through a process of negotiation between the country image and self-image (Buhmann and Ingenhoff 2015; Entman 2008).

Since the above studies mainly focus on China's outward-focused communications of environmental justice issues in the case of air pollution before 2015, this study attempts to reevaluate relevant media representations from 2015 onwards. This study aims to answer the following research questions:

RQ1: What is the proportion of coverage of environmental justice when covering China's air pollution in China's outward-focused English-language news media, China's Englishlanguage commercial news media in SARs, and Western mainstream news media respectively?

RQ2: What components of the notion of environmental justice were included in the four groups of news media and how are they ranked in application frequencies respectively?

RQ3: How were the components of the notion of environmental justice evaluated in the four groups of news media respectively?

RQ4: What are the discrepancies of journalistic constructions of the notion of environmental justice between China's outward-focused English-language news media and the other three groups of news media?

\section{Methodology}

This study investigates the media communications of environmental justice in the case of China's air pollution through the perspective of news sources. This section introduces the rationales for and procedures of selection of news media and news articles, the unit of analysis, and the research method of qualitative content analysis.

\section{Selection of News Media and News Articles}

This study examines news articles released during each December from 2015, when Beijing issued the first ever red alert for air pollution, to 2018 , when air pollution again masked many 
Chinese cities, including the capital Beijing. The month of December witnesses the heaviest air pollution in China. The issuing of red alerts for air pollution in Beijing in 2015 and 2016 all happened in the Decembers of those years (Appendix A). Although no red alerts were issued during 2017 and 2018 in Beijing, the severest air pollution also happened during the months of December (Beijing Municipal Ecological Environment Bureau 2018; Wu 2017). The Chinese government may address its policies on dealing with air pollution during these periods to the outside world. News media in other countries may also scrutinise China's governmental responses accordingly.

This study uses $C D$ to study public diplomacy communication by China's outward-focused news media. $C D$ is a Chinese, governmentally sponsored, English-language newspaper. It enjoys a leading role in providing Chinese governmental information to global readers. Regarding the news media in China's SARs, this study uses SCMP, which is a Hong Kongbased English-language quality newspaper with a high international reputation for investigation. The two newspapers have frequently been chosen by scholars as examples of China-based news media to compare different journalistic representations of China-related issues to the international audience (e.g., Chen 2018; Krumbein 2015).

The selection of American and British news media was based on two considerations. First, this study focuses on outlets that are also newspapers that paid attention to China's air pollution. This study narrowed down the search scope with the aid of the sources for 'Major US Newspapers' and 'UK Newspapers' in the database of LexisNexis by restricting the country to 'China' and requesting documents with the keywords 'smog', 'air pollution', 'PM2.5', 'haze', and/or 'particulate matter' in the body. Second, daily quality newspapers with a large daily readership were selected, which could influence the Western mainstream media discourses and public perceptions on major global issues. They may be the targets with which Chinese mainstream news media negotiate or contest news coverage patterns. Accordingly, this study uses NYT, The Wall Street Journal (WSJ), The Washington Post (WP), and USA Today (UT) to study the construction of China's image in American mainstream newspapers. The British news media selected were The Guardian $(G U)$, The Independent (IN), Financial Times (FT), The Telegraph (TE), and The Times (TI).

For $C D$, this study uses only news articles with more than 500 words to balance with the numbers of selected news articles from other news media. News articles of WSJ were retrieved from Dow Jones Factiva and all the others from LexisNexis. After sifting through the located news articles, the ones covering air pollution not with a specific focus on China, duplicates, and news briefs were excluded. Table 1 lists the number of selected news articles from each news media. 
Table 1. Number of selected news articles.

\begin{tabular}{|c|c|c|c|}
\hline $\begin{array}{l}\text { Group of news } \\
\text { media }\end{array}$ & Newspaper name & Individual number & Total number \\
\hline $\begin{array}{l}\text { China state- } \\
\text { sponsored media }\end{array}$ & $C D$ & & 139 \\
\hline $\begin{array}{l}\text { China-based media } \\
\text { in SARs }\end{array}$ & $S C M P$ & & 91 \\
\hline \multirow{4}{*}{$\begin{array}{l}\text { American } \\
\text { newspapers }\end{array}$} & $N Y T$ & 38 & 69 \\
\hline & $W S J$ & 14 & \\
\hline & $W P$ & 10 & \\
\hline & $U T$ & 7 & \\
\hline \multirow[t]{5}{*}{ British newspapers } & $G U$ & 27 & 80 \\
\hline & $I N$ & 17 & \\
\hline & $F T$ & 18 & \\
\hline & $T E$ & 7 & \\
\hline & $T I$ & 11 & \\
\hline Total & & & 379 \\
\hline
\end{tabular}

\section{Unit of Analysis}

This study explores the content of environmental justice delivered by news sources in news articles. News sources are a key element in a news article for the construction of social reality (Shoemaker and Reese 2014). The news sources include author, consultant, scholar, scientist, doctor, lawyer, news media, civil/public administration, business representative, international organisation, central administration, public, activist, artist, campaigner, and so on.

The unit of observation is the news source's statement concerning environmental justice in China's air pollution. One news article can contain two or more statements coming from different news sources concerning different components of environmental justice. The complexity of journalistic constructions of the notion of environmental justice, both in the components of the notion covered and in the tones of evaluation of each component, is evidenced through the aggregate of voices from all news sources. 


\section{Qualitative Content Analysis}

This study used the method of qualitative content analysis which refers to the 'rearticulation (interpretation) of given texts into new (analytical, deconstructive, emancipatory, or critical) narratives that are accepted within particularly scholarly communities' (Krippendorff 2004, 17). Specifically, this study employed the approach of directed qualitative content analysis (Hsieh and Shannon 2005). The codebook was informed by prior categorisations and evaluations of environmental justice and was also open to the data.

To ensure the quality of the codebook and the following coding process, this study also conducted intercoder reliability assessment (Burla et al. 2008; O'Connor and Joffe 2020). Two coders, including the author, tested their agreement on the codebook using forty-five news articles (12\% of the total sample) within which the study content was interspersed (Riffe, Lacy and Fico 2014). Intercoder reliability (Krippendorff 1978) ranged from .76 (evaluation of the component of 'adequacy') to 1.0 (presence of the component of 'rich people pay'), which was considered satisfactory in qualitative content analysis (Burla et al. 2008).

To interpret the journalistic representation patterns of environmental justice, this study combined the 'rank order comparisons of frequency of codes' and interpretation of quotations contextualised by China's public diplomacy initiatives (Hsieh and Shannon 2005, 1283).

This research method adopted the strength of quantitative methods by quantifying the notion of environmental justice, and also complemented the quantitative methods by considering the speciality of data when generating the codebook and contextualising the data when interpreting the news texts (Kracauer 1952-53).

The final codebook includes two sets of codes, i.e., components of environmental justice (what news sources say) and justice evaluation (how news sources say it).

\section{Components of Environmental Justice (What News Sources Say)}

These codes were developed from the literature specified in the explanation of the operational definition of each component of environmental justice in Table 2.

Table 2. Components of environmental justice and example quotations.

\begin{tabular}{|l|l|l|}
\hline Component & Operational definition & Quotation \\
\hline $\begin{array}{l}\text { Equality of } \\
\text { right }\end{array}$ & $\begin{array}{l}\text { Every individual and every } \\
\text { generation has an equal right } \\
\text { to use clean air (Quan 2002) }\end{array}$ & $\begin{array}{l}\text { 'Pollution cuts life expectancy, with some } \\
\text { studies suggesting it is five years shorter } \\
\text { in northern China than in the south [...]' } \\
\text { (The Guardian 2015) }\end{array}$ \\
\hline $\begin{array}{l}\text { Equality of } \\
\text { duty }\end{array}$ & $\begin{array}{l}\text { Every individual should } \\
\text { shoulder burdens to deal }\end{array}$ & $\begin{array}{l}\text { "'Everyone has a responsibility to combat } \\
\text { smog,"said Wang Xiaomei, a resident in }\end{array}$ \\
\hline
\end{tabular}

\footnotetext{
${ }^{3}$ The list of the cited news articles is included in Appendix B.
} 


\begin{tabular}{|c|c|c|}
\hline Component & Operational definition & Quotation \\
\hline & $\begin{array}{l}\text { with air pollution (Quan } \\
\text { 2002) }\end{array}$ & $\begin{array}{l}\text { Xinxiang City, Henan [...]' (China Daily } \\
\text { 2016) }\end{array}$ \\
\hline Special need & $\begin{array}{l}\text { Assistance should be } \\
\text { provided to the vulnerable } \\
\text { groups of people (Colquitt } \\
\text { and Rodell 2015) }\end{array}$ & $\begin{array}{l}\text { 'Issuing the red alert can help reduce the } \\
\text { risk of exposing vulnerable populations } \\
\text { like children and elderly people to severe } \\
\text { pollution. In this sense, it is a good move } \\
\text { by the government.' (Wei 2016) }\end{array}$ \\
\hline $\begin{array}{l}\text { Polluter's } \\
\text { responsibility }\end{array}$ & $\begin{array}{l}\text { The current polluter and the } \\
\text { polluter who has } \\
\text { accumulated emissions } \\
\text { should deal with air } \\
\text { pollution (Schmidt 2012) }\end{array}$ & $\begin{array}{l}\text { 'In Beijing alone, about } 2,100 \text { factories } \\
\text { shut down or limited operation during the } \\
\text { alert, according to the Municipal } \\
\text { Commission of Economy and Information } \\
\text { Technology.' (Abkowitz and Spegele } \\
\text { 2015) }\end{array}$ \\
\hline $\begin{array}{l}\text { Rich people } \\
\text { pay }\end{array}$ & $\begin{array}{l}\text { Rich individuals should deal } \\
\text { with air pollution (Harris } \\
\text { 2010) }\end{array}$ & $\begin{array}{l}\text { '[ }[\ldots] \text { the congestion charge will be of } \\
\text { advantage to the rich because they can } \\
\text { afford to pay peak-hour tolls.' (Ying } \\
2015 \text { ) }\end{array}$ \\
\hline $\begin{array}{l}\text { Rights } \\
\text { recognition }\end{array}$ & $\begin{array}{l}\text { The public's rights in } \\
\text { legislation or governmental } \\
\text { plans concerning air } \\
\text { pollution mitigation should } \\
\text { be recognised (Balme 2014) }\end{array}$ & $\begin{array}{l}\text { 'The 13th Five-Year Plan is a progressive } \\
\text { plan because it says that the public has the } \\
\text { right to participate, to monitor, and that } \\
\text { it's the public's right to know.' (Tatlow } \\
\text { 2016) }\end{array}$ \\
\hline $\begin{array}{l}\text { Openness and } \\
\text { participation }\end{array}$ & $\begin{array}{l}\text { The decision-making and } \\
\text { execution of air pollution } \\
\text { mitigation should be open to } \\
\text { the public's voices and } \\
\text { involvement (Colquitt and } \\
\text { Rodell 2015; Schmidt 2012) }\end{array}$ & $\begin{array}{l}\text { 'If there is a silver lining in the heavy } \\
\text { smog, it should be the emerging chance } \\
\text { policymakers can seize to galvanize as } \\
\text { much public support as possible and the } \\
\text { public's participation in what promises to } \\
\text { be a long hard fight against air pollution.' } \\
\text { (Zhu 2015) }\end{array}$ \\
\hline Adequacy & $\begin{array}{l}\text { Air pollution should be } \\
\text { addressed in an all-around } \\
\text { (not partial), timely (not } \\
\text { outdated), and accurate (not } \\
\text { wrong) way (Colquitt and } \\
\text { Rodell 2015) }\end{array}$ & $\begin{array}{l}\text { 'Greenpeace praised the Orange Alert that } \\
\text { had been declared for putting restrictions } \\
\text { on construction and industry, but said that } \\
\text { it was "clearly not enough."' (Griffin } \\
\text { 2015) }\end{array}$ \\
\hline Transparency & $\begin{array}{l}\text { Information concerning air } \\
\text { pollution reasons, } \\
\text { consequences, and solutions } \\
\text { should be accessible }\end{array}$ & $\begin{array}{l}\text { '[...] public pressure has resulted in } \\
\text { greater official transparency on air } \\
\text { quality.' (Wong 2015b) }\end{array}$ \\
\hline
\end{tabular}




\begin{tabular}{|l|l|l|}
\hline Component & $\begin{array}{l}\text { Operational definition } \\
\text { (Colquitt and Rodell 2015; } \\
\text { Schmidt 2012) }\end{array}$ & Quotation \\
\hline Reversibility & $\begin{array}{l}\text { Policies about air pollution } \\
\text { mitigation can be adjusted or } \\
\text { corrected when they are not } \\
\text { efficient (Colquitt and } \\
\text { Rodell 2015; Schmidt 2012) }\end{array}$ & $\begin{array}{l}\text { 'But a shortage of natural gas to replace } \\
\text { coal heating systems left many households } \\
\text { in freezing temperatures, forcing the } \\
\text { authorities into a U-turn on the ban.' } \\
\text { (Shen 2018) }\end{array}$ \\
\hline Litigation & $\begin{array}{l}\text { Recognition of } \\
\text { environmental rights can be } \\
\text { obtained through litigation } \\
\text { (Balme 2014) }\end{array}$ & $\begin{array}{l}\text { 'To [...] improve public interest litigation } \\
\text { on environmental protection...China has } \\
\text { enacted the Law on Environmental } \\
\text { Protection Tax.' (China Daily 2017) }\end{array}$ \\
\hline
\end{tabular}

\section{Justice Evaluation (How News Sources Say It)}

This study adapted the scale of perceived inequality (Huang 2018) to investigate news sources' evaluation of environmental justice. The study coded the content about environmental justice voiced by news sources using a three-point scale $(1=$ 'disagree'/equivalent to environmental injustice; 2 = 'no obvious attitude'; 3 = 'agree'/equivalent to environmental justice). Example quotations are included in Table 3.

Table 3. Categories of justice evaluation and example quotations.

\begin{tabular}{|l|l|}
\hline Category & Quotation \\
\hline $1=$ 'disagree' & $\begin{array}{l}\text { 'Several lawyers are suing the cities of Beijing and Tianjin and Hebei } \\
\text { province for what they say has been their failure to fulfil responsibilities in } \\
\text { battling the smog.' (Agerholm 2016) }\end{array}$ \\
\hline $\begin{array}{l}2=\text { 'no } \\
\text { obvious } \\
\text { attitude' }\end{array}$ & $\begin{array}{l}\text { 'Beijing warned a week ago that a heavy bout of smog was expected, and } \\
\text { issued a 'red alert', which involves closing factories, shutting schools, and } \\
\text { also forcing a large proportion of cars off the road.' (Connor 2016) }\end{array}$ \\
\hline $3=$ 'agree' & $\begin{array}{l}\text { 'China is making progress battling pollution through effective measures } \\
\text { like reducing coal consumption and increasing electric vehicles, which } \\
\text { could inspire other countries, the UN environment head said.' (Zheng } \\
\text { 2016) }\end{array}$ \\
\hline
\end{tabular}

\section{Research Findings}

\section{Proportion of Coverage}

Figure 1 illustrates the proportions that different groups of news media devoted to 
environmental justice issues when covering China's air pollution incidents. It should be noted that the range of issues that are considered as environmental justice in this study may not be exhaustive, but it is safe to say that the data provides an overview of relevant coverage. This research found that the studied media all mentioned environmental justice issues in more than half of their coverage of China's air pollution. American newspapers devoted more attention to pertaining issues (63.8\%) than others, while $C D$ devoted the least $(51.1 \%)$.

Figure 1. Proportions of coverage of environmental justice issues in different news media.

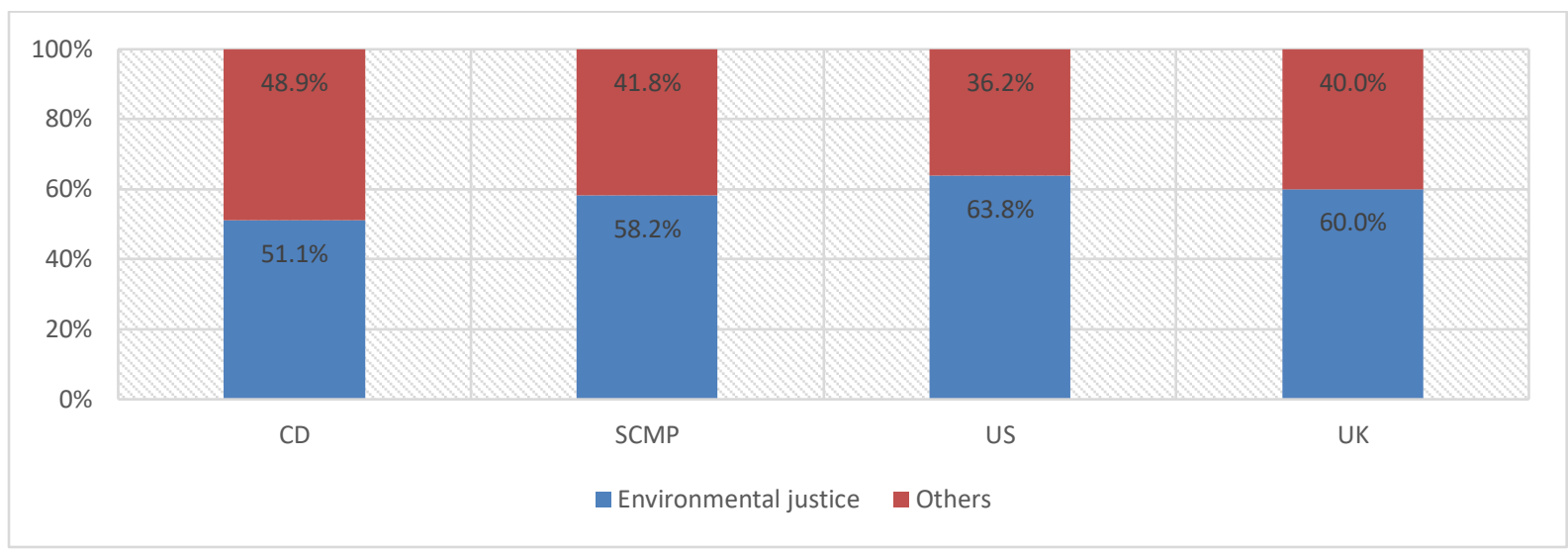

\section{What News Sources Say}

$C D$ quoted mostly from news sources mentioning the components of, in the order of frequency, 'polluter's responsibility', 'adequacy', 'special need', and 'openness and participation' in the notion of environmental justice, which echoes the coverage pattern by British newspapers. $S C M P$ and American newspapers covered the element of 'adequacy' most frequently and paid substantial attention to 'polluter's responsibility', 'special need', and 'openness and participation'.

$C D$ paid overwhelming attention to the element of 'polluter's responsibility' through the voices of news sources ( $36.1 \%$ of all the statements from the news sources, see Figure 2). For example, on 7 December 2015, when Beijing issued the first ever red alert for heavy air pollution, $C D$ covered a range of polluters, including the 'pollution sources such as coal burning' and the 'vehicles that cannot meet national emission standard' (China Daily 2015a). A series of following news articles reiterated the component of 'polluter's responsibility' by covering, for example, the mandatory emergency measures towards heavy polluters such as heavy goods vehicles, activities at construction sites, and fireworks and outdoor barbecues (China Daily 2015c) and the monitoring of power plants, steel and metal works in the Beijing-Tianjin-Hebei area (Jinran 2015). Similarly, two days after Beijing issued the first red alert for smog in 2016, an article mentioned the restrictions imposed on polluters such as cars, suspensions of construction sites, strengthening of inspections and monitoring of factories, and the proposal of industry optimisation across the country (China Daily 2016). 
Figure 2. $C D$ 's coverage of environmental justice in China's air pollution.

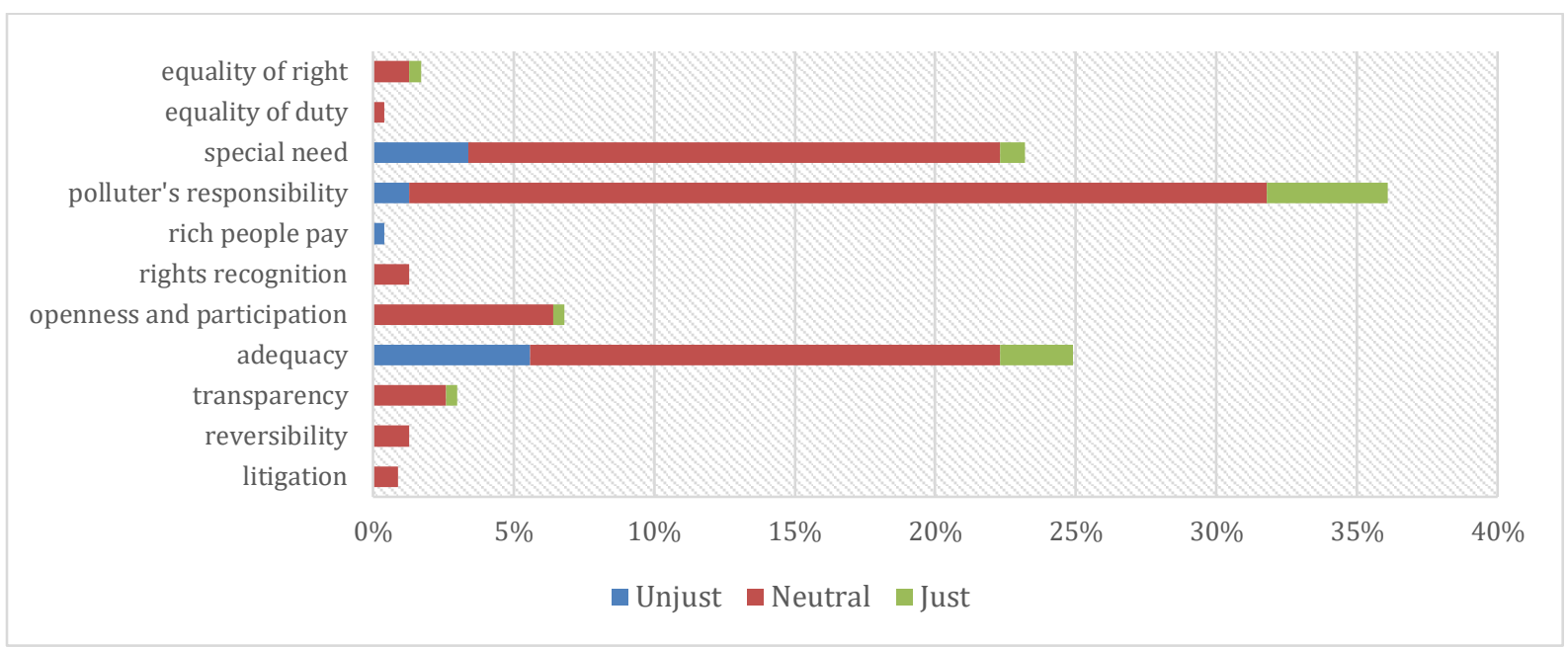

Figure 3 shows that British newspapers also paid the most attention to 'polluter's responsibility' with a roughly similar proportion $(35.5 \%)$ when covering issues related to environmental justice in China's air pollution. Selected samples mentioned China's suspension of factories (Connor and Lomas 2015), cars (Pak 2015), and coal-fired power plants (Gabbatiss 2018; Hornby and Zhang 2017).

Figure 3. British newspapers' coverage of environmental justice in China's air pollution.

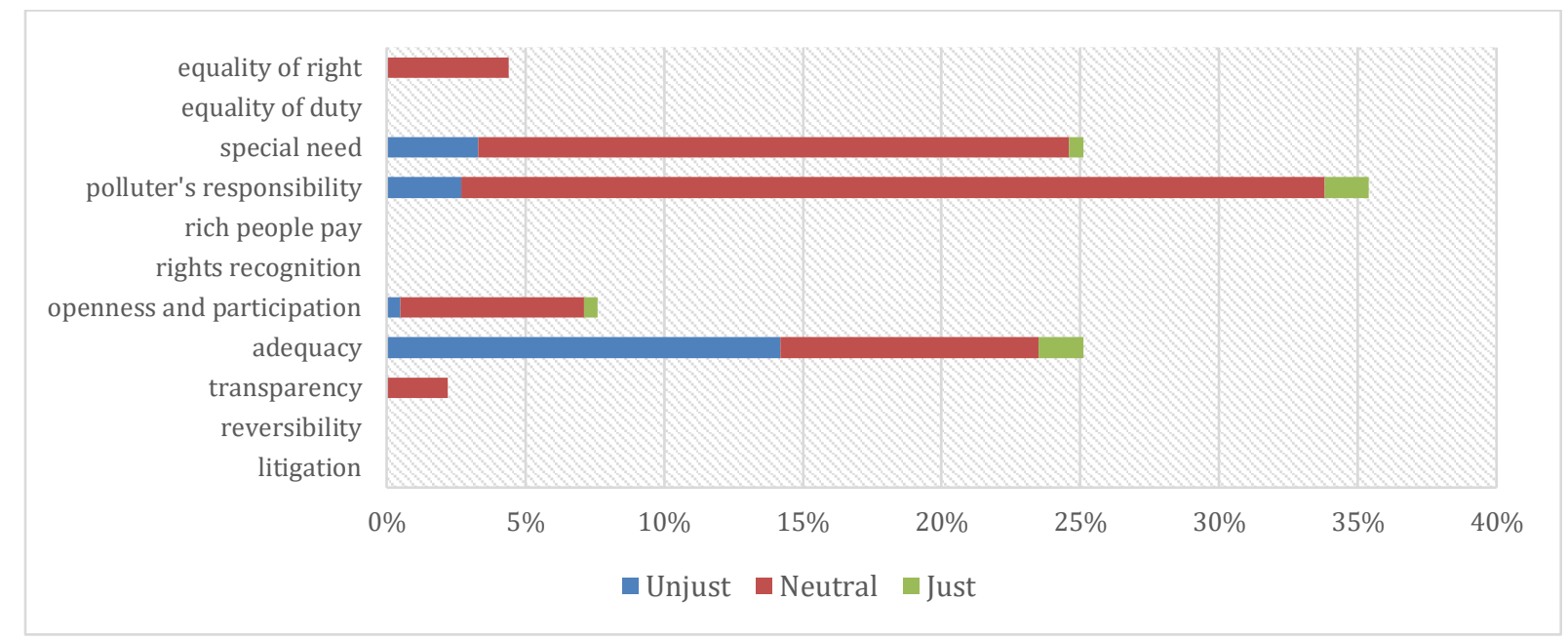

The component of 'polluter's responsibility' ranked second in the overall coverage in SCMP and American newspapers (30.6\% and 27.9\% respectively; see Figures 4 and 5). Similar coverages of the restrictions on cars and companies appeared in SCMP (Zhou 2017b; Zhuang 2015), USA Today (Bacon 2016), and NYT (Huang 2015). 
Figure 4. SCMP's coverage of environmental justice in China's air pollution.

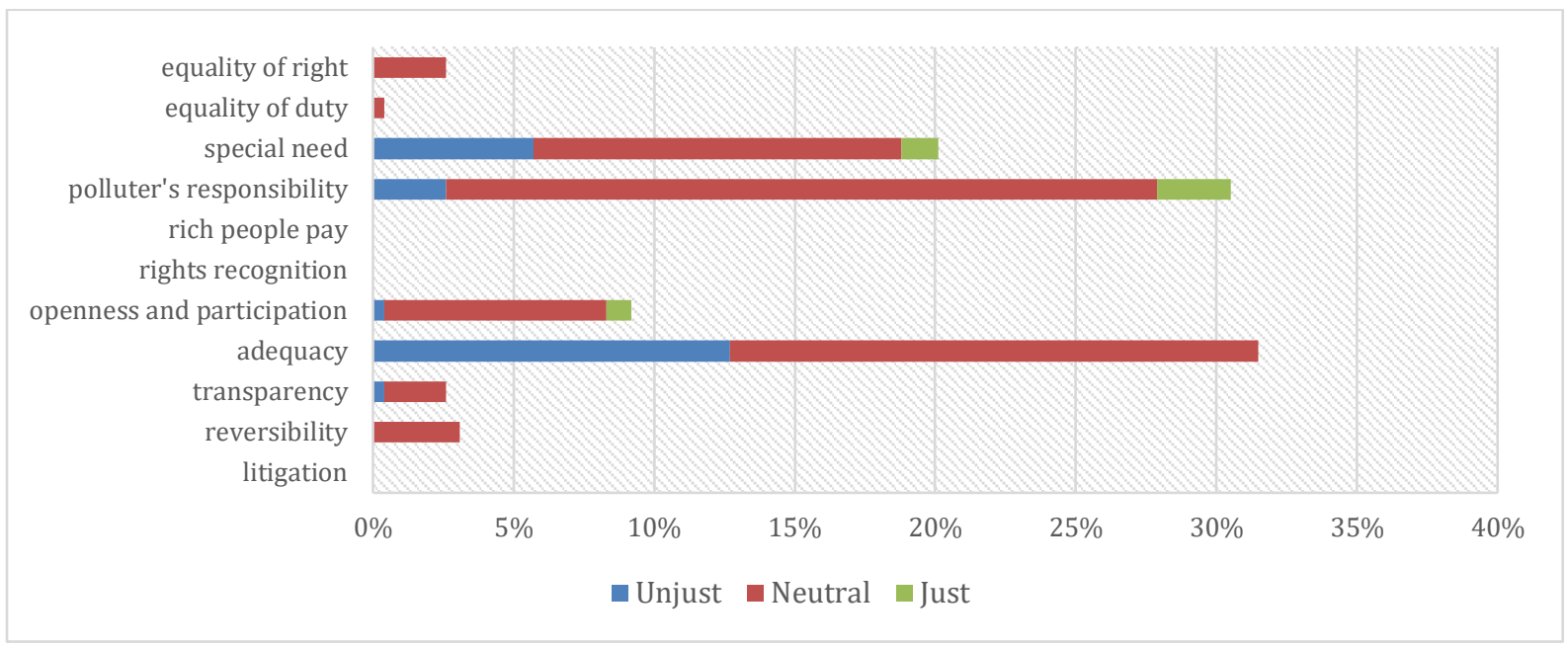

Figure 5. American newspapers' coverage of environmental justice in China's air pollution.

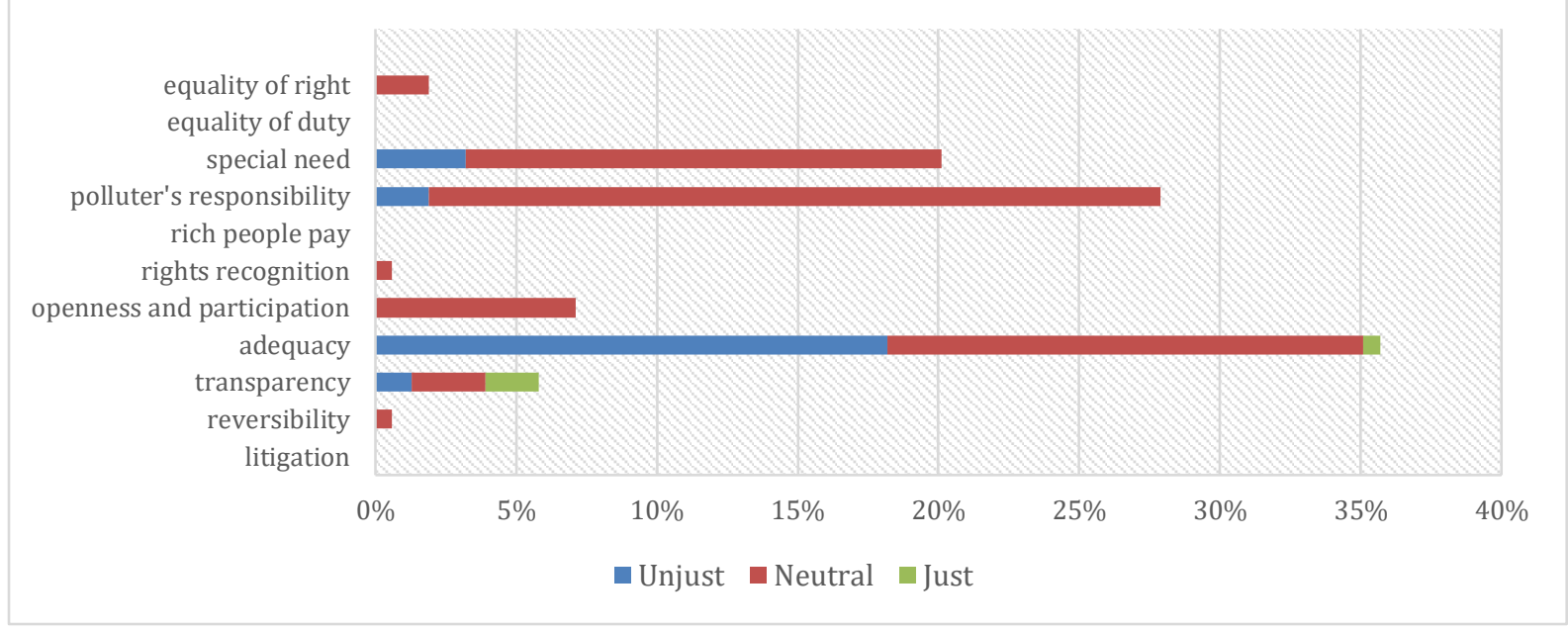

Both SCMP and American newspapers put most focus on the 'adequacy' of the decisionmaking and execution procedures in achieving environmental justice in China's air pollution ( $31.4 \%$ and $35.7 \%$ respectively). For instance, WSJ covered the inconvenience caused by the regulations of restrictions on cars in Beijing to people such as those making a living on ridehailing services (Abkowitz and Spegele 2015), exposing that the policies issued could not account for both the health needs and the living demands of the public. Moreover, WP reported the petition launched by parents in Beijing asking the government to install air purifiers in schools for the sake of their children's health (Parnass 2017). The 'poorly thought-out measures' were also covered by SCMP which focused on people suffering from unstable energy supplies during winter (Zhou 2017a). The category of 'adequacy' was also given considerable attention by $C D(24.9 \%)$ and British newspapers $(25.1 \%)$. Regarding the insufficient heating supplies, $C D$ covered that the central government 'urged officials in North China to visit homes to ensure that everyone is receiving heat' (Liqiang et al. 2017). Another 
$C D$ article also mentioned the inadequate infrastructure development of heating equipment in rural areas in China and the public's concerns for higher prices of cleaner coal (Zheng and Wang 2015). British newspapers pointed out the inaccuracy of information issued by the Beijing government in merely classifying the smog as a weather disaster instead of a manmade consequence (Yang et al. 2016) and the failure to issue a timely red alert to avoid harms to the public's health (Phillips 2015).

The component of 'special need' was ranked as the third most frequently quoted category (the same as the category of 'adequacy' in British newspapers) and was given a similar proportion of attention in the four groups of news media (CD, 23.2\%; SCMP, 20.1\%; US, 20.1\%; UK, $25.1 \%$ ). For example, the agendas of primary (Connor 2017; Zhao 2015) and middle school students' health (Buckley 2016) and demands of people in low-income areas in China (Shen $S C M P, 2018$ ) were included in the news media. 'Openness and participation' appeared as the fourth most quoted element across the four groups of news media ( $C D, 6.9 \%$; SCMP, 9.2\%; US, 7.1\%; UK, 7.7\%), although it received much less attention. A few news articles covered the Chinese government's statement of inviting citizens for city planning (China Daily 2015b), the elimination of social media calls for protest over air pollution (Tang SCMP, 2016), Beijing government's releasing of real-time data on PM 2.5 as a response to public's demands (Wong 2015a), and lawyers' action to bring a case against local governments for being incapable of executing environmental laws (Yang FT, 2016). Almost all the other components were covered in only less than $5 \%$ of all the statements from news sources (one exception is that $5.8 \%$ of statements from news sources covered the aspect of 'transparency' in American newspapers).

\section{How News Sources Say It}

Regarding the news sources' evaluation of the individual component of the notion of environmental justice, $C D$ had a similarly neutral way of covering 'polluter's responsibility', 'special need', and 'openness and participation' compared to those by the other three groups of news media. However, when covering 'adequacy', $C D$ adopted a neutral tone while the other three groups of news media used more critical voices. In an overall sense, all news media constructed environmental justice in a dominantly neutral way. $C D$ quoted opinions from news sources viewing environmental justice in China's air pollution in a less unjust and more just way than those quoted in other news media.

The concept of 'polluter's responsibility' was overwhelmingly perceived neutrally by news sources across the four groups of news media ( $C D, 30.5 \%$ neutral statements and $5.6 \%$ others; SCMP, $25.3 \%$ neutral statements and 5.2\% others; US, $26 \%$ neutral statements and $1.9 \%$ others; UK, $31.1 \%$ neutral statements and $4.3 \%$ others). Several excerpts in Table 4 show that no judgments were provided by news sources when covering the polluter's responsibilities for dealing with the air pollution. 
Table 4. Excerpts about 'polluter's responsibility'.

\begin{tabular}{|l|l|}
\hline $\begin{array}{l}\text { News } \\
\text { media }\end{array}$ & Excerpt \\
\hline$C D$ & $\begin{array}{l}\text { '[...] according to Hebei Provincial Working Group Office for Prevention and } \\
\text { Control of Air Pollution [...] } 10 \text { areas in Hebei province [...] were [...] required to } \\
\text { build a better technical capacity to implement prevention and control measures, } \\
\text { such as equipment to reduce pollution and monitor the PM10 concentrations at } \\
\text { construction sites.' (Zhang 2018) }\end{array}$ \\
\hline$S C M P$ & $\begin{array}{l}\text { '[...] local cadres [...] confiscated coal briquettes and locked up people who } \\
\text { continued selling the polluting fuel [...] state media said.' (Zhou 2017a) }\end{array}$ \\
\hline$T E$ & $\begin{array}{l}\text { 'Beijing required over 2,100 major companies in polluting industries to suspend } \\
\text { their production,' the state-run China Daily said on Tuesday.' (Connor and Lomas } \\
\text { 2015) }\end{array}$ \\
\hline$U T$ & $\begin{array}{l}\text { 'Under a contingency plan for severe air pollution, the city shut down more than } \\
700 \text { heavy-industry plants and required 500 more to reduce production, the South } \\
\text { China Morning Post reported.' (Bacon 2016) }\end{array}$ \\
\hline
\end{tabular}

The same pattern was found when portraying the component of 'special need' $(C D, 18.9 \%$ neutral statements and 4.3\% others; SCMP, $13.1 \%$ neutral statements and $7 \%$ others; US, $16.9 \%$ neutral statements and $3.2 \%$ others; UK, $21.3 \%$ neutral statements and $3.8 \%$ others). Some examples of neutral statements are included below in Table 5.

Table 5. Excerpts about 'special need'.

\begin{tabular}{|c|c|}
\hline $\begin{array}{l}\text { News } \\
\text { media }\end{array}$ & Excerpt \\
\hline$C D$ & $\begin{array}{l}\text { '"[...] The breathing mask I'm wearing is actually issued by the department, and } \\
\text { there are also some warning text messages on the air pollution." Lu Liancang, 50, } \\
\text { road cleaner.' (Zheng 2015) }\end{array}$ \\
\hline$S C M P$ & $\begin{array}{l}\text { 'Liu said the factory provided drinking water to about } 100 \text { households who could } \\
\text { not afford to move away and still lived in the village.' (Li 2016) }\end{array}$ \\
\hline$W P$ & $\begin{array}{l}\text { 'On Jan. 4, parents in Beijing fed up with the thick lingering smog sickening their } \\
\text { children launched a petition demanding the government put air purifiers in } \\
\text { schools.' (Parnass 2017) }\end{array}$ \\
\hline$F T$ & $\begin{array}{l}\text { "'It's cold! Brrr!" a migrant cleaning woman surnamed Chen [...] Her landlord } \\
\text { began forbidding coal stoveheaters early this year, in line with the new } \\
\text { regulations.' (Hornby and Zhang 2017) }\end{array}$ \\
\hline
\end{tabular}


The news sources quoted by the four groups of news media also made neutral statements about the element of 'openness and participation' $(C D, 6.4 \%$ neutral statements and $0.4 \%$ others; SCMP , 7.9\% neutral statements and $1.3 \%$ others; US, $7.1 \%$ neutral statements and $0 \%$ others; UK, $6.6 \%$ neutral statements and $1 \%$ others) in environmental justice in China's air pollution as illustrated by the following examples in Table 6.

Table 6. Excerpts about 'openness and participation'.

\begin{tabular}{|l|l|}
\hline $\begin{array}{l}\text { News } \\
\text { media }\end{array}$ & Excerpt \\
\hline$C D$ & $\begin{array}{l}\text { 'The government will take a more sophisticated approach to its urban planning, } \\
\text { and encourage enterprises and citizens to participate in creating the cities of the } \\
\text { future, according to the statement.' (China Daily 2015b) }\end{array}$ \\
\hline$S C M P$ & $\begin{array}{l}\text { 'The municipal government released a list of } 80 \text { local polluting plants, including } \\
\text { steel, cement and papermaking firms, late on Friday to call for public supervision, } \\
\text { in an apparent bid to ease local anger.' (Tang 2016) }\end{array}$ \\
\hline$N Y T$ & $\begin{array}{l}\text { 'This week's red alert was the latest step seeking to loosen up discussion of } \\
\text { environmental hazards and to allow citizens to vent their frustration. Beijing } \\
\text { officials have even thanked the city's residents for their response, writing in an } \\
\text { open letter on Thursday, "The dedication and full support of the people of Beijing } \\
\text { touched us deeply." (Wong 2015a) }\end{array}$ \\
\hline$F T$ & $\begin{array}{l}\text { '[...] wrote another online commenter. "The people are under too much pressure - } \\
\text { if we try to protest, we're said to be "creating public disorder."' (Yang et al. 2016) }\end{array}$ \\
\hline
\end{tabular}

A contrast appeared in the media's constructions of the aspect of 'adequacy'. $C D$ still represented it in a dominantly neutral way (16.7\% neutral statements comparing with $5.6 \%$ unjust and $2.6 \%$ just statements). Although SCMP also cited news sources mainly delivering a neutral evaluation of 'adequacy' (18.8\%), the unjust perceptions $(12.7 \%)$ doubled those by $C D$. The unfair perceptions constituted about half of all the statements concerning 'adequacy' in US newspapers (18.2\% unjust and 17.5\% other statements) and dominated those in British newspapers (14.2\% unjust and $10.9 \%$ other statements). 
Table 7. Excerpts about 'adequacy'.

\begin{tabular}{|l|l|}
\hline $\begin{array}{l}\text { News media } \\
\text { and tone of } \\
\text { coverage }\end{array}$ & Excerpt \\
\hline$C D$ (neutral) & $\begin{array}{l}\text { 'Rui Wengang, director of the environmental protection bureau, said: "We } \\
\text { have highlighted the comprehensive application of scientific and } \\
\text { technological means to prevent and control the air pollution this winter." } \\
\text { (Nan 2018) }\end{array}$ \\
\hline SCMP (unjust) & $\begin{array}{l}\text { 'Authorities faced fierce criticism late last month after they failed to issue } \\
\text { the highest warning when the city was blanketed by pollution for five } \\
\text { consecutive days. Many parents complained that their children should } \\
\text { have been told to stay at home.' (Zhou 2015) }\end{array}$ \\
\hline NYT (unjust) & $\begin{array}{l}\text { '[...] Lin Boqiang, an energy analyst at Xiamen University. "In planning } \\
\text { the emissions goals, the government has not really coordinated well with } \\
\text { gas producers."' (Bradsher 2017) }\end{array}$ \\
\hline$T E$ (unjust) & $\begin{array}{l}\text { 'Campaign group Greenpeace criticised authorities in Beijing for issuing } \\
\text { only their second highest alert, behind "red" which would have forced cars } \\
\text { of the road.' (Connor and Lomas 2015) }\end{array}$ \\
\hline
\end{tabular}

Almost all the other components were viewed mainly as being neutral by the news sources across the four groups of news media (one exception is $C D$ 's construction of the component of 'rich people pay' which was depicted as being unjust but only with a proportion of $0.4 \%$ ).

Figure 6 shows that the notion of environmental justice in the case of China's air pollution was dominantly constructed in a neutral tone across the four groups of news media. Nevertheless, the news sources applied by $C D$ perceived the notion in a much less unjust, and indeed more just, way than those quoted in other news media.

Figure 6. The overall tone of journalistic constructions of environmental justice in China's air pollution in four groups of news media.

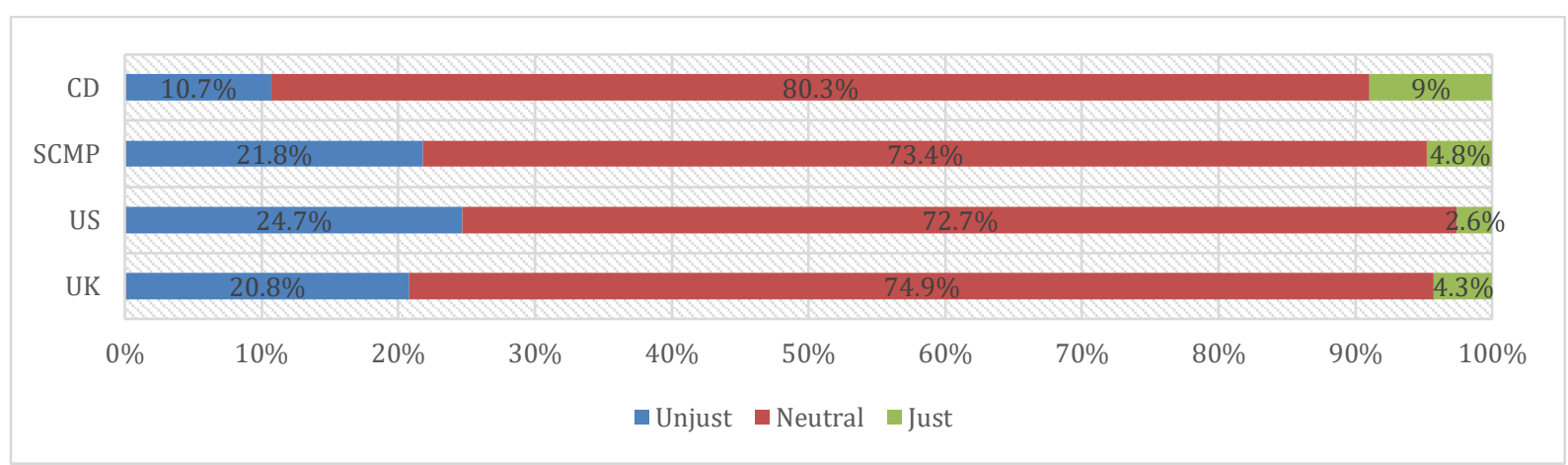




\section{Discussion and Conclusion}

This study re-evaluated media communications of 'public', and specifically the domestic public's interests related to environmental justice embedded in the case of China's air pollution, in China's public diplomacy. This study found that China's outward-focused news media $C D$ continued to cover issues related to environmental justice in the case of China's air pollution after 2015. Besides covering the general policy schemes in dealing with the domestic public's interests in air pollution, $C D$ extended its coverage to the reasons underlying the air pollution and the public's detailed demands. It mainly adopted a neutral tone in covering the notion of environmental justice. These aspects of self-image share similarities with the images constructed by news media from China SARs, the US, and the UK. An obvious discrepancy appears in constructing the element of 'adequacy' between $C D$ and the other three groups of media, with the former still being neutral in coverage and the latter three adopting more critical voices. Findings are discussed in the context of China's public diplomacy initiatives.

Firstly, this study found that, in congruence with news coverage before 2015 (e.g., 2011-2014, see Liu and Zhang 2018), CD continued to include the agenda of air pollution in its news coverage from 2015 to 2018. $C D$ also included statements from news sources concerning the notion of environmental justice in about half of the located news articles. This may be a reflection of the issuing of the red alerts for air pollution, which pressures the state-sponsored media to cover relevant issues to overseas audiences. The coverage of China's air pollution and the involved environmental justice issues by SCMP and US and British news media also indicates the pressure that China's state-sponsored media was under not to hide from the issues in which its domestic publics had stakes.

Secondly, in terms of the components of environmental justice included in the statements of news sources, the results show that the four groups of news media all covered 'polluter's responsibility', 'adequacy', and 'special need' in more than $20 \%$ of all the statements and 'openness and participation' in more than 5\%, although $C D$ and British media paid most attention to 'polluter's responsibility', and SCMP and US media to 'adequacy'. This observation shows the consistency of China's mediated international communication in covering the overall architecture of governmental policies in dealing with air pollution issues ('adequacy') (Chen 2018; Liu and Li 2017). It also manifests an extension of the scope of the content of communication. $C D$ also exposed the general causes of air pollution ('polluter's responsibility') and the detailed demands from the public, especially those from the vulnerable groups ('special need') and those concerning the public's involvement in the decision-making and execution procedures ('openness and participation'). The extensions may be a result of being conscious of the country images constructed by other news media. Elements such as 'rights recognition' and 'rich people pay' seldom received attention. The minimal focus on 'transparency' indicates that the Chinese government no longer put emphasis on the explanation of smog as identified by studies on relevant media communications before 2015 (e.g., Chen 2018; Liu and Li 2017).

Thirdly, as to the evaluation of the components of environmental justice, the news sources quoted by $C D$ mainly neutrally judged 'polluter's responsibility', 'special need', and 'openness 
and participation', and the notion of environmental justice in an overall sense, which shows consistency with Ran Duan and Bruno Takahashi's (2017) findings. The neutral tone adopted by $C D$ resonates with those in the other three groups of news media. One of the reasons for $C D$ 's neutral tone may be that maintaining congruence with other news media in depicting the elements of 'polluter's responsibility', 'special need', and 'openness and participation' and the notion of environmental justice in an overall sense may work more favourably for China's public diplomacy initiatives. The balance between China's self-image as constructed by its state-sponsored media and China's image as constructed by other news media (Buhmann and Ingenhoff 2015; Entman 2008) may facilitate the acceptance of China's policies in dealing with environmental justice issues in the case of air pollution among overseas countries (Golan 2013; Nye 2008).

The contrast of the evaluation of the components of environmental justice between $C D$ and other groups of news media appears in the evaluation of 'adequacy'. $C D$ again quoted more neutral voices, while British and US media adopted more critical ones. SCMP mainly used neutral opinions, but its quotations of environmental injustice doubled those by $C D$. The underlying reason for the contrast may be attributed to the connotation of the component of 'adequacy' which points directly to the appropriateness and legitimacy of China's governmental policies in dealing with the domestic public's interests in the case of air pollution. $C D$, as a governmentally-sponsored news media, was cautious in questioning the timeliness, comprehensiveness, and preciseness of governmental policies in managing the environmental justice issues embedded in air pollution.

Responding to the textual turn of public diplomacy research (Zhao 2021), this study enriches academic understandings of the communication patterns of the social and ecological (Buhmann and Ingenhoff 2015) and the humanitarian and environmental (Yun 2006) responsibilities of a country towards its domestic public to the outside world as a part of its public diplomacy initiatives.

Empirically, this study provides insights into China's evolving governmental stances in dealing with environmental justice issues in the case of air pollution. Compared with those before 2015, the current messages delivered by the Chinese government through the state-sponsored news media under the scheme of public diplomacy shifted to a more humanitarian perspective. It may be a step by the Chinese government in striving to gain more acceptance from the global community for its management of environmental and social justice issues. It may also serve as a chess move that the Chinese government uses to shape the global environmental politics. Whether these manoeuvres have exerted impact on China's country image deserves close and updated scholarly investigations.

This research is limited by its sole focus on news articles released during each December from 2015 to 2018. Although December witnesses the heaviest air pollution in China, the air problem also exists during October, November, January, and even some warmer months. Future research may usefully test the research findings of this study by examining a larger size of samples across a longer period. This could enhance the transferability of the findings (Kracauer 1952-53). Scholars may also benefit from testing and refining the above framework of 
environmental justice to uncover China's mediated international communication of other environmental issues, which is extremely valuable to understanding China's actions in shaping global environmental politics. Besides examining relevant journalistic representations by $C D$, future research can also investigate the construction of environmental justice by China's state actors on other platforms, especially English-language social media sites such as Twitter and Facebook. These platforms have been leveraged by China's state actors to practice public diplomacy. It would be intriguing to see whether the discourses delivered by traditional outward-focused media channels and their corresponding social media accounts are consistent. This could provide insights into the intricacies of China's public diplomacy activities as different platforms are targeted at different groups of overseas audiences. 


\section{Appendix A}

Red alerts for heavy air pollution issued by the Beijing Municipal Emergency Management Office.

\begin{tabular}{|c|c|}
\hline Issue date & Time span \\
\hline $\begin{array}{l}7 \text { December } 2015 \\
\text { (Available at: } \\
\text { http://society.people.com.cn/n/2015/1207/c1 } \\
\text { 008-27897940.html) }\end{array}$ & $\begin{array}{l}\text { 7am, } 8 \text { December } 2015 \text { - 12am, } 10 \\
\text { December } 2015 \\
\text { (Available at: } \\
\text { http://zfxxgk.beijing.gov.cn/dxq353/qt1/201 } \\
\text { 5-12/08/content_dxq6423153.shtml) }\end{array}$ \\
\hline $\begin{array}{l}18 \text { December } 2015 \\
\text { (Available at: } \\
\text { http://zfxxgk.beijing.gov.cn/11K000/bmdt5 } \\
\underline{2 / 2015-12 / 28 / \text { content } 653738 . s h t m l} \text { ) }\end{array}$ & $\begin{array}{l}\text { 7am, } 19 \text { December } 2015 \text { - 12pm, } 22 \\
\text { December } 2015 \\
\text { (Available at: } \\
\text { http://zfxxgk.beijing.gov.cn/11K000/bmdt5 } \\
\underline{2 / 2015-12 / 28 / \text { content_653738.shtml) }}\end{array}$ \\
\hline $\begin{array}{l}15 \text { December } 2016 \\
\text { (Available at: } \\
\text { http://zfxxgk.beijing.gov.cn/dxq347/gzdt/20 } \\
\text { 16-12/15/content_dxq6506221.shtml; } \\
\text { http://www.beijing.gov.cn/bmfw/zxts/t1462 } \\
\underline{468 . h t m)}\end{array}$ & $\begin{array}{l}\text { 8pm, } 16 \text { December } 2016 \text { - 12pm, } 21 \\
\text { December } 2016 \\
\text { (Available at: } \\
\text { http://zfxxgk.beijing.gov.cn/dxq347/gzdt/20 } \\
\underline{16-12 / 15 / \text { content_dxq6506221.shtml; }} \\
\underline{\text { http://www.beijing.gov.cn/bmfw/zxts/t1462 }} \\
\underline{468 . h t m)}\end{array}$ \\
\hline
\end{tabular}




\section{Appendix B}

List of cited news articles:

Abkowitz, A., and Spegele B. (2015) 'World News: Beijing's Smog Fight Illustrates Growth Dilemma', The Wall Street Journal, 11 December.

Agerholm, H. (2016) 'Chinese 'Airpocalypse' Affects Half-a-Billion People as Smog Crisis Worsens', The Independent, 20 December. Available at:

https://www.independent.co.uk/news/world/asia/china-airpocalypse-smog-air-pollutionlevels-red-alert-beijing-a7487261.html (Accessed: 19 September 2021).

Bacon, J. (2016) ‘China Smog Clogs Human, Jet Airways', USA Today, 20 December.

Bradsher, K. (2017) 'Even Spandex is Hit by An Energy Squeeze', The New York Times, 13 December.

Buckley, C. (2016) 'Smog Grips China, but Exams Goes On’, The New York Times, 22 December.

China Daily (2015a) 'Beijing Issues First Red Alert for Heavy Air Pollution', 7 December. Available at: https://www.chinadaily.com.cn/china/2015-12/07/content_22652539.htm (Accessed: 19 September 2021).

China Daily (2015b) 'China Seeks to Make Cities Better Places to Live In', 22 December.

China Daily (2015c) 'Seven Urgent Questions about Beijing's First Red Smog Alert', December 8. Available at: https://www.chinadaily.com.cn/china/201512/08/content_22660890.htm (Accessed: 19 September 2021).

China Daily (2016) 'China Combats Heavy Smog with Red Alerts', 18 December.

China Daily (2017) 'New Progress in Legal Protection of Human Rights in China', 16 December. Available at:

https://www.chinadaily.com.cn/a/201712/16/WS5a34995aa3108bc8c6735089.html (Accessed: 19 September 2021).

Connor, N. (2016) 'China Headmaster 'Suspended' after 400 Pupils Sit Exam Outside during Heavy Smog', The Telegraph, 21 December. Available at: https://www.telegraph.co.uk/news/2016/12/21/china-headmaster-suspended-400-pupils-sitexam-outside-heavy/ (Accessed: 19 September 2021).

Connor, N. (2017) 'Chinese Schools Investigated for Holding Classes Outside During Freezing Winter', The Telegraph, 6 December. Available at: https://www.telegraph.co.uk/news/2017/12/06/probe-launched-china-schools-hold-classesoutside-freezing-winter/ (Accessed: 19 September 2021).

Connor, N. and Lomas C. (2015) 'What Is It Like to Live in the Beijing Smog?', The Telegraph, 7 December. 
Gabbatiss, J. (2018) 'China's War on Air Pollution Causing Increase in Dangerous Ozone, New Study Warns', The Independent. 31 December. Available at:

https://www.independent.co.uk/climate-change/news/china-air-pollution-ozone-beijingshanghai-research-study-science-a8705936.html (Accessed: 19 September 2021).

Griffin, A. (2015) 'Beijing Smog 'Red Alert' Issued', The Independent. 7 December. Available at: https://www.independent.co.uk/climate-change/news/beijing-smog-red-alertissued-schools-and-businesses-to-completely-shut-down-as-chinese-capital-issues-first-everextreme-warning-a6763286.html (Accessed: 19 September 2021).

The Guardian (2015) 'Editorial: The Guardian View on Beijing's Smog Alert: Dealing with the Symptom not the Cause', 20 December. Available at:

https://www.theguardian.com/commentisfree/2015/dec/20/the-guardian-view-on-beijingsmog-alert-dealing-with-the-symptom-not-the-cause (Accessed: 19 September 2021).

Hornby, L., and Zhang A. (2017) 'Beijing's Shift Away from Coal Leads to Gas Shortages', Financial Times, 4 December. Available at: https://www.ft.com/content/21cb4ed2-d7f911e7-a039-c64b1c09b482 (Accessed: 19 September 2021).

Huang, S. (2015) 'Chinese-Language Readers Speak Out on the Emissions Challenge', The New York Times, 9 December. Available at:

https://www.nytimes.com/2015/12/10/world/asia/china-climate-change-smog-pollution.html (Accessed: 19 September 2021).

Jinran, Z. (2015) 'Beijing Sees First Red Alert over Smog', China Daily, 8 December. Available at https://www.chinadaily.com.cn/cndy/2015-12/08/content_22654890.htm (Accessed: 19 September 2021).

Li, J. (2016) 'In Steel Heartland, Mills Bring Jobs and Poison Skies', South China Morning Post, 22 December.

Liqiang, H., Juan, D., Jinran, Z. and Yu, Z. (2017) 'Energy Initiative to Cut Smog Worsens Winter Gas Shortage', China Daily, 15 December. Available at: https://www.chinadaily.com.cn/a/201712/15/WS5a3300a6a3108bc8c6734c18.html (Accessed: 19 September 2021).

Nan, H. (2018) 'Air Quality Up, Living Conditions Improve in Gansu's Provincial Capital', China Daily, 12 December. Available at: https://www.chinadaily.com.cn/cndy/201812/12/content 37392434.htm (Accessed: 19 September 2021).

Pak, J. (2015) 'Beijing Issues Second Ever 'Red Alert' Ahead of Thick Smog', The Telegraph, 18 December. Available at: https://www.telegraph.co.uk/news/worldnews/asia/china/12057307/China-issues-freshpollution-warning.html (Accessed: 19 September 2021).

Parnass, S. (2017) '17 of 2017's Most Visual Stories from Around the World', Washington Post, 27 December. Available at:

https://www.washingtonpost.com/news/worldviews/wp/2017/12/27/17-of-2017s-most-visualstories-from-around-the-world/ (Accessed: 19 September 2021). 
Phillips, T. (2015) 'Beijing Issues First Pollution Red Alert as Smog Engulfs Capital', The Guardian, 8 December. Available at:

https://www.theguardian.com/environment/2015/dec/07/beijing-pollution-red-alert-smogengulfs-capital (Accessed: 19 September 2021).

Shen, A. (2018) 'Officials in North Clamp Down on Heating Fuel Abuses', South China Morning Post, 12 December.

Tang, F. (2016) 'Smog Protest Quickly Snuffed Out', South China Morning Post, 11 December.

Tatlow, D. K. (2016) 'China Has Made Strides in Addressing Air Pollution, Environmentalist Says.' The New York Times, 16 December. Available at:

https://www.nytimes.com/2016/12/16/world/asia/china-air-pollution-ma-jun.html (Accessed: 19 September 2021).

Wei, V. (2016) 'Beijing Braces for Extreme Smog', South China Morning Post, 17 December.

Wong, E. (2015a) 'Polluted Skies Heighten Challenge for Chinese Government', The New York Times, 10 December. Available at:

https://www.nytimes.com/2015/12/11/world/asia/china-smog-challenge.html (Accessed: 19 September 2021).

Wong, E. (2015b) 'World Briefing: Asia: China: 'Red Alert' on Beijing's Air', The New York Times, 18 December.

Yang, Y. (2016) 'China Faces Lawsuit on 'Red Alert' Smog', Financial Times, 22

December.

Yang, Y., Zhang A., and Ju S. F. (2016) 'Smog Shutdown: China 'Airpocalypse' Engulfs 24 Cities', Financial Times, 21 December.

Ying, W. (2015) 'Proper Use of Congestion Fee can Cut Traffic Jams', China Daily, 15 December. Available at: https://www.chinadaily.com.cn/opinion/201512/15/content_22714509.htm (Accessed: 19 September 2021).

Zhang, Y. (2018) 'Public Servants Summoned Over Air Pollution in Hebei', China Daily, 27 December. Available at:

http://www.chinadaily.com.cn/a/201812/27/WS5c240b36a310d912140511ef.html (Accessed: 19 September 2021).

Zhao, X. (2015) 'Parents Try to Clear Air for Children at Beijing Schools', China Daily, 30 December. Available at: https://www.chinadaily.com.cn/china/201512/30/content_22861849.htm (Accessed: 19 September 2021).

Zheng, J. (2016) 'China Hailed for Pollution Control Effort', China Daily, 10 December. Zheng, J. (2015) 'Debate Flares as Smog Lingers', China Daily. 9 December. Available at: https://www.chinadaily.com.cn/china/2015-12/09/content_22666005.htm (Accessed: 19 September 2021). 
Zheng, J. and Wang Y. (2015) 'Low-Grade Coal is Cheaper, but Poses Pollution Challenge', China Daily, 21 December. Available at: https://www.chinadaily.com.cn/china/201512/21/content_22758869.htm (Accessed: 19 September 2021).

Zhou, L. (2015) 'Smog Triggers Warnings Across North', South China Morning Post, 23 December.

Zhou, V. (2017a) 'Dash to Gas Backfires', South China Morning Post, 20 December.

Zhou, V. (2017b) 'Push for Higher Green Tax on Mainland Polluters', South China Morning Post, 16 December.

Zhu, Q. (2015) 'Environmental Crisis Calls for Smarter, Flexible Responses', China Daily, 3 December. Available at: http://www.chinadaily.com.cn/cndy/201512/03/content_22612268.htm (Accessed: 19 September 2021).

Zhuang, P. (2015) 'On Mainland, Face Masks Outselling Condoms Online', South China Morning Post, 10 December. 


\section{References}

Balme, R. (2014) 'Mobilising for Environmental Justice in China.' Asia Pacific Journal of Public Administration, 36(3), pp. 173-184.

BBC News (2015) 'China Pollution: First Ever Red Alert in Effect in Beijing', 8 December. Available at: https://www.bbc.com/news/world-asia-china-35026363 (Accessed: 19 September 2021.)

Beijing Municipal Ecological Environment Bureau (2018) Woshi yu 2018 nian 12 yиe 1 ri 0 shi qidong kongqi zhongwuran huangse yujing cuoshi [Beijing Issued Yellow Alert for Air Pollution from 0am 1 December 2018], 30 November. Available at: http://hbj.beijing.gov.cn/wap/gzdt43/842986/index.html (Accessed: 19 September 2021).

Buhmann, A., and Ingenhoff, D. (2015) 'The 4D Model of the Country Image: An Integrative Approach from the Perspective of Communication Management', International Communication Gazette, 77(1), pp. 102-124.

Burla, L., Knierim, B., Barth, J., Liewald, K., Duetz, M., and Abel, T. (2008) 'From Text to Codings: Intercoder Reliability Assessment in Qualitative Content Analysis', Nursing Research, 57(2), pp. 113-117.

Chen, S. (2018) 'Exploring the Formation of the "Leave-It-To-Experts" Storyline During the Initial Outbreak of the 2013 Smog Hazard in Beijing', Chinese Journal of Communication, 11(4), pp. 385-399.

Chen, W., Tu F., and Zheng P. (2017) 'A Transnational Networked Public Sphere of Air Pollution: Analysis of a Twitter Network of PM2. 5 from the Risk Society Perspective', Information, Communication \& Society, 20(7), pp. 1005-1023.

Chen, Y. (2014) 'Exploring the Attitudinal Variations in the Chinese English-Language Press on the 2013 Air Pollution Incident', Discourse \& Communication, 8(4), pp. 331-349.

Cheng, Z., Golan G. J., and Kiousis S. (2016) 'The Second-Level Agenda-Building Function of the Xinhua News Agency', Journalism Practice, 10(6), pp. 744-762.

Colquitt, J. A., and Rodell J. B. (2015) 'Measuring Justice and Fairness', in Cropanzano, R. S. and Ambrose, M. L. (eds.) The Oxford Handbook of Justice in the Workplace. New York, NY: Oxford University Press, pp. 187-202.

Duan, R., and Takahashi B. (2017) 'The Two-Way Flow of News: A Comparative Study of American and Chinese Newspaper Coverage of Beijing's Air Pollution', International Communication Gazette, 79(1), pp. 83-107.

Entman, R. M. (2008) 'Theorizing Mediated Public Diplomacy: The U.S. Case', The International Journal of Press/Politics, 13(2), pp. 87-102.

Golan, G. J. (2013) 'An Integrated Approach to Public Diplomacy', American Behavioral Sciences, 57(9), pp. 1251-1255. 
Guo, Y., and Li, Y. (2018) 'Online Amplification of Air Pollution Risk Perception: The Moderating Role of Affect in Information', Information, Communication \& Society, 21(1), pp. 80-93.

Harris, P. G. (2010) World Ethics and Climate Change: From International to Global Justice. Edinburgh: Edinburgh University Press.

Hartig, F. (2015) 'Communicating China to the World: Confucius Institutes and China's Strategic Narratives.' Politics, 35(3-4), pp. 245-258.

Hsieh, H. F., and Shannon S. E. (2005) 'Three Approaches to Qualitative Content Analysis', Qualitative Health Research, 15(9), pp. 1277-1288.

Huang, Q. (2018) 'Public Trust in Local Governments and Environmental Risks in China: The Effects of Media Use, Perceived Dread, and Perceived Inequality', Chinese Journal of Communication, 11(1), pp. 88-104.

Huang, Z. A., and Wang R. (2019) 'Building a Network to "Tell China Stories Well”: Chinese Diplomatic Communication Strategies on Twitter', International Journal of Communication, 13, pp. 2984-3007.

Hunt, K., and Lu, S. (2015) 'Smog in China Closes Schools and Construction Sites, Cuts Traffic in Beijing', $C N N, 8$ December. Available at: https://edition.cnn.com/2015/12/07/asia/china-beijing-pollution-red-alert/index.html (Accessed: 19 September 2021).

Jia, R. and Li, W. (2020) 'Public Diplomacy Networks: China's Public Diplomacy Communication Practices in Twitter during Two Sessions', Public Relations Review, 46(1), 101818 .

Kopra, S. (2015) 'China's Consideration of Ethics and Justice Issues in Formulating Climate Change Policies', in Brown, D.A. and Taylor, P. (eds.), Ethics and Climate Change: A Study of National Commitments. Gland, Switzerland: IUCN, pp. 53-61.

Kracauer, S. (1952-53) 'The Challenge of Qualitative Content Analysis', Public Opinion Quarterly, 16, pp. 631-642.

Krippendorff, K. (2004) Content Analysis: An Introduction to Its Methodology. 2nd edn. Thousand Oaks, CA: Sage.

Krippendorff, K. (1978) 'Reliability of Binary Attribute Data', Biometrics, 34(1), pp. 142144.

Krumbein, F. (2015) 'Media Coverage of Human Rights in China', International Communication Gazette, 77(2), pp. 151-170.

Liu, M., and Li, C. (2017) 'Competing Discursive Constructions of China's Smog in Chinese and Anglo-American English-Language Newspapers: A Corpus-Assisted Discourse Study', Discourse \& Communication, 11(4), pp. 386-403. 
Liu, M., and Zhang Y. (2018) 'Discursive Constructions of Scientific (Un)certainty about the Health Risks of China's Air Pollution: A Corpus-Assisted Discourse Study', Language \& Communication, 60, pp. 1-10.

Moernaut, R., Mast J., and Pepermans Y. (2018) 'Reversed Positionality, Reversed Reality? The Multimodal Environmental Justice Frame in Mainstream and Alternative Media', International Communication Gazette, 80(5), pp. 476-505.

Nye, J. S. (2008) 'Public Diplomacy and Soft Power', The Annals of the American Academy of Political and Social Science, 616(1), pp. 94-109.

O’Connor, C., and Joffe, H. (2020) 'Intercoder Reliability in Qualitative Research: Debates and Practical Guidelines', International Journal of Qualitative Methods, 19, pp. 1-13.

Ouyang, W., Gao B., Cheng H., Hao Z., and Wu N. (2018) 'Exposure Inequality Assessment for $\mathrm{PM}_{2.5}$ and the Potential Association with Environmental Health in Beijing', Science of the Total Environment, 635, pp. 769-778.

Park, S. J., and Lim, Y. S. (2014) 'Information Networks and Social Media Use in Public Diplomacy: A Comparative Analysis of South Korea and Japan', Asian Journal of Communication, 24(1), pp. 79-98.

Quan, R. (2002) 'Establishing China's Environmental Justice Study Models', Georgetown International Environmental Law Review, 14(3), pp. 461-487.

Riffe, D., Lacy S., and Fico F. (2014) Analyzing Media Messages: Using Quantitative Content Analysis in Research. 3rd edn. New York: Routledge.

Rusciano, F. L. (2003) 'The Construction of National Identity - a 23-Nation Study', Political Research Quarterly, 56(3), pp. 361-366.

Schmidt, A. (2012) 'Justice in the Public Climate Debate: Claims \& Related Policy Preferences in Comparative Perspective', Paper prepared for the 24th International Climate Policy Ph.D. Workshop, Freiburg. doi:10.13140/2.1.1907.2008

Shoemaker, P. J., and Reese S. D. (2014) Mediating the Message in the 21st Century: A Media Sociology Perspective. New York and London: Routledge.

Sun, C., Kahn M. E., and Zheng S. (2017) 'Self-Protection Investment Exacerbates Air Pollution Exposure Inequality in Urban China’, Ecological Economics, 131, pp. 468-474.

Sun, W. (2014) 'Foreign or Chinese? Reconfiguring the Symbolic Space of Chinese Media', International Journal of Communication, 8, pp. 1894-1911.

Wong, E. (2015), 'Beijing Issues Red Alert Over Air Pollution for the First Time', New York Times, 8 December. Available at: https://www.nytimes.com/2015/12/08/world/asia/beijingpollution-red-alert.html (Accessed 19 September 2021).

Wu, M. (2006) 'Framing AIDS in China: A Comparative Analysis of US and Chinese Wire News Coverage of HIV/AIDS in China', Asian Journal of Communication, 16(3), pp. 251272. 
$\mathrm{Wu}, \mathrm{X}$. (2017) '2017 nian rudong zuiqiang wumai tianqi laixi, quanguo jin 90 cheng fabu yujing [The Severest Smog Invaded China in 2017 and Nearly 90 Cities in China Issued Alerts for Air Pollution]', Caixin.com, 29 December. Available at: http://china.caixin.com/2017-12-29/101191263.html (Accessed: 19 September 2021).

Yang, A., Wang, R., and Wang, J. (2017) 'Green Public Diplomacy and Global Governance: The Evolution of the U.S-China Climate Collaboration Network, 2008-2014', Public Relations Review, 43(5), pp. 1048-1061.

Yun, S-H. (2006) 'Toward Public Relations Theory-Based Study of Public Diplomacy: Testing the Applicability of the Excellence Study', Journal of Public Relations Research, 18(4), pp. 287-312.

Zhang, T., Khalitova L., Myslik B., Mohr, T.L., Kim, J.Y. and Kiousis, S. (2018) 'Comparing Chinese State-Sponsored Media's Agenda-Building Influence on Taiwan and Singapore Media during the 2014 Hong Kong Protest', Chinese Journal of Communication, 11(1), pp. 66-87.

Zhao X. (2021) 'Journalistic Construction of Congruence: Chinese Media's Representation of Common but Differentiated Responsibilities in Environmental Protection', Journalism, 22(8), pp. 2139-2157.

Dr Xin Zhao is a lecturer at the Department of Communication and Journalism at Bournemouth University. Her research broadly explores media representations, media audience, and journalism practice surrounding the topic of social justice, such as environmental justice and racial equality. Her works have been published in journals such as Journalism, Journalism Studies, Asian Journal of Communication, and Global Media and Communication. Email: $\underline{x z h a o @ b o u r n e m o u t h . a c . u k}$ 